\title{
Epstein-Barr virus infection and gastric carcinoma in São Paulo State, Brazil
}

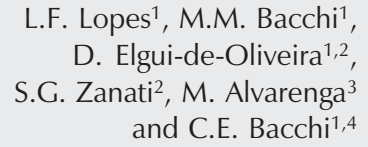

Correspondence

\section{C.E. Bacchi}

Consultoria em Patologia

Rua Major Leônidas Cardoso, 739

18602-010 Botucatu, SP

Brasil

E-mail:

bacchi@consultoriapatologia.com.br

Research supported by FAPESP

(No. 95/6579-0).

Received February 27, 2004

Accepted August 25, 2004
${ }^{1}$ Consultoria em Patologia, Botucatu, SP, Brasil

2Departamento de Patologia, Faculdade de Medicina de Botucatu, Universidade Estadual de São Paulo, Botucatu, SP, Brasil

${ }^{3}$ Departamento de Tocoginecologia, Faculdade de Ciências Médicas,

Universidade Estadual de Campinas, Campinas, SP, Brasil

${ }^{4}$ Hospital Israelita Albert Einstein, São Paulo, SP, Brasil

\begin{abstract}
Epstein-Barr virus (EBV) is a ubiquitous herpesvirus, and most people have serological evidence of previous viral infection at adult age. EBV is associated with infectious mononucleosis and human cancers, including some lymphomas and gastric carcinomas. Although EBV was first reported in lymphoepithelioma-like gastric carcinoma, the virus was also found in conventional adenocarcinomas. In the present study, 53 gastric carcinomas diagnosed in São Paulo State, Brazil, were evaluated for EBV infection by non-isotopic in situ hybridization with a biotinylated probe (Biotin-AGACACCGTCCTCACCACCC GGGACTTGTA) directed to the viral transcript EBER-I, which is actively expressed in EBV latently infected cells. EBV infection was found in 6 of $53(11.32 \%)$ gastric carcinomas, mostly from male patients $(66.7 \%)$, with a mean age of 59 years old. Most EBV-positive tumors were in gastric antrum. Two EBV-positive tumors $(33.3 \%)$ were conventional adenocarcinomas, whereas four $(66.7 \%)$ were classified as lymphoepithelioma-like carcinomas. EBV infection in gastric carcinomas was reported elsewhere in frequencies that range from $5.6 \%$ (Korea) up to $18 \%$ (Germany). In Brazil, a previous work found EBV infection in 4 of $80(5 \%)$ gastric carcinomas, whereas another study found 4.7 and $11.2 \%$ of EBV-positive gastric carcinomas of Brazilians of Japanese origin or not, respectively. In the present study, the frequency of EBV-positive gastric carcinomas is similar to that reported in other series, and the clinicopathologic characteristics of these EBV-positive tumors are in agreement with the data in the literature.
\end{abstract} Key words - Epstein-Barr virus - Gastric carcinoma - In situ hybridization - Brazil

\section{Introduction}

Epstein-Barr virus (EBV) has been associated with a variety of lymphoid and epithelial malignancies, such as Burkitt's lymphoma $(1,2)$, Hodgkin's disease $(3,4)$, T-cell lym- phomas (5,6), AIDS-related lymphomas (7, $8)$, nasopharyngeal carcinoma $(1,9,10)$, and lymphoepithelioma-like carcinomas (LELC) of several organs including salivary glands (11), thymus $(12,13)$, and lung (14).

Early in the 1990s, some papers reported 
the association between gastric carcinoma and EBV infection. Burke et al. (15) first detected EBV in a LELC of the stomach by the polymerase chain reaction, and other investigators also confirmed this finding (1621). LELC is an uncommon type of gastric carcinoma $(17,19,22)$ strongly associated with $\mathrm{EBV}$, with this association ranging from 77.8 to $87.5 \%$ of cases $(17,19-21)$. Occurrence in elderly patients, male predominance, gastric cardia and middle portion involvement in most cases, and high survival rates were described in association with gastric LELC $(17,19,20,22)$.

In 1991, Shibata et al. (17) first presented a case of EBV-positive conventional gastric carcinoma. Several investigators subsequently added new information regarding the prevalence and clinicopathologic characteristics of EBV infection in gastric carcinomas of different populations from North, Central and South America, Europe and Asia; however, there are few reports concerning clinicopathologic data of EBV-related gastric carcinomas among Brazilians, including one study that compares characteristics of EBV-positive gastric carcinomas from Brazilians of Japanese origin or not (23).

Thus, the aim of the present study was to provide additional information about the prevalence and characteristics of EBV infection in gastric carcinomas diagnosed in São Paulo State, Brazil, and compare the results with other series of EBV-positive gastric cancer elsewhere.

\section{Material and Methods}

\section{Case selection}

Fifty-three gastrectomy specimens with gastric carcinomas diagnosed in the Department of Pathology, State University of São Paulo (Botucatu, SP, Brazil), were included in this study. Representative formalin-fixed paraffin-embedded blocks from the tumor, surrounding non-neoplastic gastric mucosa, and regional lymph nodes with metastases were selected. Gastric carcinomas were classified according to the Lauren's classification. The undifferentiated and lymphoepithelioma-like types of carcinoma were also considered for classification, and the criteria for diagnosis of LELC were applied as described by Watanabe et al. (22). Clinicopathologic data were obtained from pathology reports, including patient age and sex as well as the anatomical site of the tumor (cardia, middle portion or antrum) and the histologic type of carcinoma.

All cases were confirmed as carcinomas with the demonstration of keratin reactivity by immunohistochemistry. Of the 53 patients studied, 35 were males and 17 were females. The gender of one patient was not available. Mean age was 58.8 years, ranging from 30 to 80 years.

\section{In situ hybridization}

EBV infection was assessed by RNA in situ hybridization with a 30-bp biotinylated probe(Biotin-AGACACCGTCCTCACCAC CCGGGACTTGTA) for RNA EBER-I, an EBV transcript actively expressed in latently infected cells. Briefly, tissue sections were placed on poly-D-lysine-treated glass slides and incubated at $70^{\circ} \mathrm{C}$ for one day. After the slides were routinely deparaffinized, endogenous peroxidase was blocked with $3 \% \mathrm{H}_{2} \mathrm{O}_{2}$ solution. Enzymatic digestion was performed with proteinase $\mathrm{K}(0.02 \mu \mathrm{g} / \mu 1$ final concentration) and the tissues were then dehydrated in ethanol and dried at room temperature. The slides were incubated in prehybridization solution (20 mM sodium phosphate/ Denhardt's solution $1 \mathrm{X} / 0.1 \%$ dextran sulfate) for $60 \mathrm{~min}$ at $37^{\circ} \mathrm{C}$. After the addition of the EBER-I probe $(0.25 \mathrm{ng} / \mathrm{ml}$ final concentration), tissues were incubated overnight at $37^{\circ} \mathrm{C}$ in a humid chamber. The signal was amplified with the $\mathrm{ABC}$ Elite kit (Vector Corp., Burlingame, CA, USA), and the reaction was developed with 3,3'-diaminobenzi- 
dine (Sigma, St. Louis, MO, USA) solution. The slides were counterstained with methyl green and mounted with Permount ${ }^{\circledR}$ resin (Fischer Chemicals Inc., Fair Law, NJ, USA). A case of nasopharynx LELC previously known to be EBV positive was used as positive control. The cells presenting a positive signal for EBV EBER-I RNA had dark brown to black nuclear staining.

\section{Results}

EBER-I was positive in 6 of the 53 cases $(11.3 \%)$. Five of the 6 positive cases $(83.3 \%)$ were male patients, with a mean age of 59 years, ranging from 52 to 67 years. The only female patient with an EBER-I-positive gastric carcinoma was 65 years old.

\section{Pathologic and in situ hybridization findings}

According to the anatomical site of the gastric carcinoma, $22(41.5 \%)$ carcinomas were present in the antrum, $6(11.3 \%)$ in the middle portion of the stomach, and 5 (9.4\%) in the cardia. Unfortunately, information regarding the anatomical site was unavailable for $3 \mathrm{EBV}$-positive cases. Two (33.3\%) of the $6 \mathrm{EBV}$-positive cases were localized in the antrum and one (16.6\%) in the middle portion of the stomach.

The distribution of the histological types of carcinomas (including EBV-positive cases) is shown in Table 1. Among the 6 EBV-positive carcinomas, 2 (33.3\%) were conventional carcinomas of tubular (Figure 1A) and undifferentiated types (Figure 1E), and $4(66.7 \%)$ were LELC (Figure 1C). The EBER-I signal was uniformly distributed in the nuclei of carcinoma cells in all 6 positive cases (Figure 1B,D,F). The surrounding lymphocytes and non-neoplastic gastric mucosa with chronic gastritis or intestinal metaplasia were EBV negative. It is worth noting that $\mathrm{EBV}$ sequences were also detected in a case with metastatic carcinoma in regional lymph nodes. This finding indicates that the metastatic gastric carcinoma recapitulates the EBV infection in the neoplastic cells from the primary tumor.

\begin{tabular}{lcc}
\multicolumn{2}{l}{ Table 1. Distribution of gastric carcinomas in } & \multicolumn{3}{l}{ Brazilian patients by histologic type. } \\
\hline Histologic types & Total & EBER-I-positive cases \\
\hline Intestinal (including tubular adenocarcinoma) & $27(51.0 \%)$ & $1(37 \%)$ \\
Diffuse & $18(34 \%)$ & $-(0 \%)$ \\
Undifferentiated & $1(1.8 \%)$ & $1(100 \%)$ \\
LELC & $7(13.2 \%)$ & $4(57.1 \%)$ \\
Total & $53(100 \%)$ & $6(11.3 \%)$ \\
\hline
\end{tabular}

LELC, Iymphoepithelioma-like carcinoma.

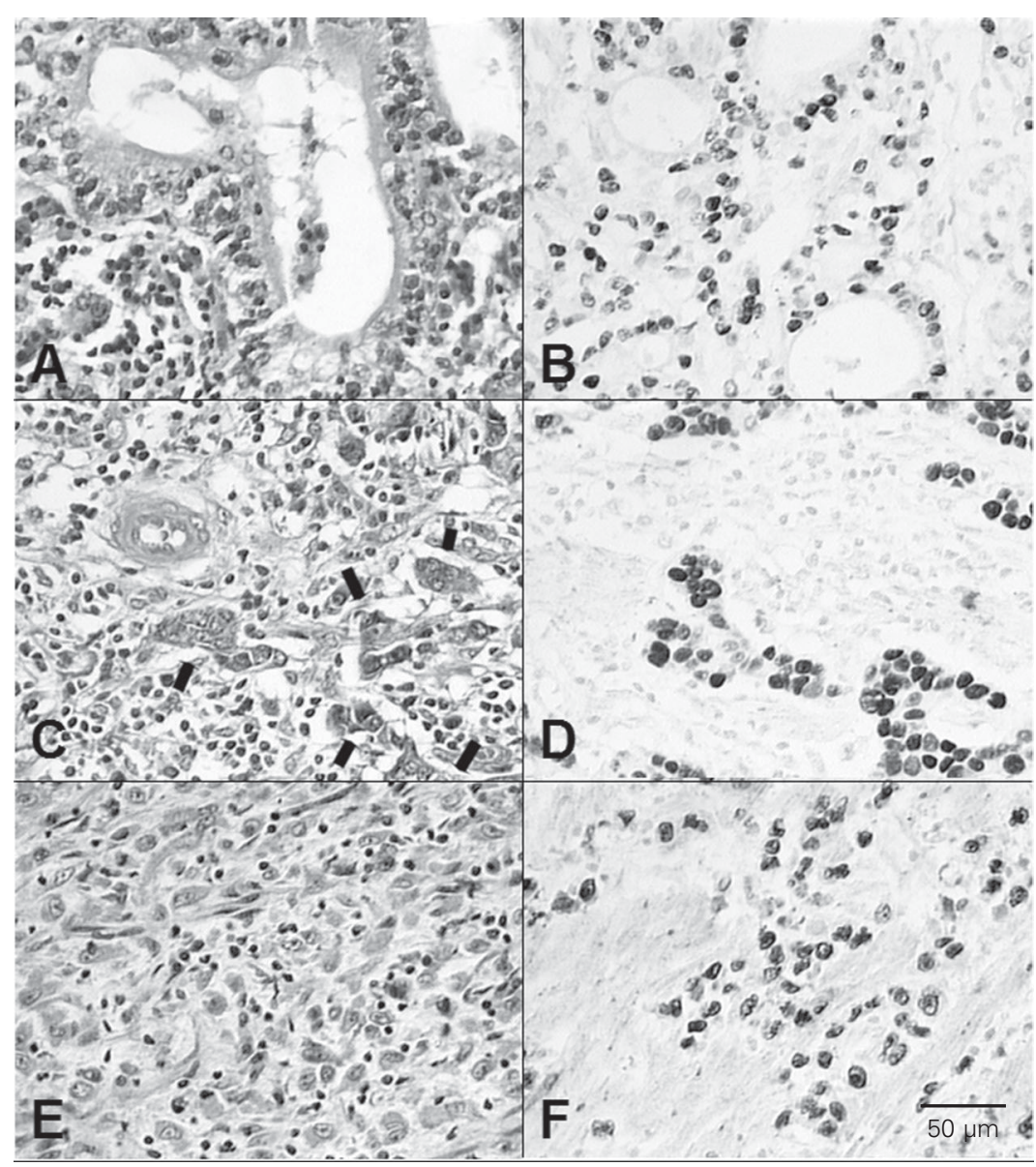

Figure 1. Photomicrographs of the Epstein-Barr virus-positive carcinomas. A, Tubular adenocarcinoma (hematoxylin and eosin, 400X). B, Tubular adenocarcinoma showing nuclear EBER-I signals (EBER-I, 400X). C, Lymphoepithelioma-like carcinoma (hematoxylin and eosin, 400X). D, Lymphoepithelioma-like carcinoma showing nuclear EBER-I signals (EBER-I, 400X). E, Undifferentiated carcinoma (hematoxylin and eosin, 400X). F, Undifferentiated carcinoma showing nuclear EBER-I signals (EBER-I, 400X). 


\section{Discussion}

The Brazilian National Cancer Institute (Instituto Nacional do Câncer, INCA) reports 20,000 new cases of gastric cancer yearly, and it is believed that about 11,000 patients die because of the disease (24). Diet, smoking, alcohol intake, previous gastric surgery, and some gastric diseases, such as pernicious anemia, gastritis and Helicobacter pylori infection, are considered to be risk factors for the development of cancer. The association between EBV and gastric cancer was first detected by Burke et al. (15), and many reports showing this strong association have been published since then.

The frequency of EBV-positive gastric carcinomas can reach up to $18 \%(19,21$, 23,25-39), as reported in Germany (39). In Eastern countries, e.g., Japan, China and Taiwan, EBV-positive gastric cancer comprises 5.6 to $13.5 \%$ of cases $(19,21,29-36)$. In Russia, Galetsky et al. (37) reported a frequency of $8.7 \%$. In the US (including Hawaii) and Mexico, 8.15 to $16 \%$ of gastric carcinomas were EBV positive (25-28).

In Brazil, Hayashi et al. (40) found EBV infection in 4 of $80(5.0 \%)$ gastric carcinomas of Brazilian patients, and in 29 of 510 (5.7\%) gastric carcinomas of Japanese patients. Few EBV-positive gastric carcinomas (9/33 cases or $27.3 \%)$ were classified as LELC. This might explain the lower rate of EBV infection observed in these tumors. In a study published in 2001, Koriyama et al. (23) reported 4.7 and $11.2 \%$ of EBV-positive gastric carcinomas in Brazilians of Japanese origin $(\mathrm{N}=148)$ or not $(\mathrm{N}=150)$, respectively. Interestingly, all these EBVpositive gastric carcinomas were classified as conventional carcinomas. In the present study, the frequency of EBV infection in gastric carcinomas was $11.32 \%$, and most of them were classified as LELC $(4 / 6,66.7 \%)$.

Occurrence in elderly persons and male predominance are common in EBV-associated gastric carcinomas $(23,25,27,29,31-37)$, and these findings were also observed in the present study. However, the site where EBVpositive gastric carcinoma more often arises is a controversial issue in the literature. Some studies have reported that the cardia and middle portion of the stomach are more frequently involved (29-31,33,37), whereas others have found that the antrum was the most typical site $(23,28,32)$. In the present study, the antrum was the most common anatomic site involved by EBV-positive gastric carcinomas. Moderately to poorly differentiated conventional carcinomas and diffuse histology have also been associated with EBVpositive gastric cancers $(23,27-29,31-33,36$, 37 ), but the prognosis does not seem to be influenced by these characteristics $(27,36)$. Unfortunately, no additional information is available regarding the follow-up of the patients with EBV-positive gastric carcinomas included in the present study.

EBV infection in gastric carcinomas in São Paulo State, Brazil, as well as their clinicopathologic characteristics, are similar to those reported for other countries. Additional studies are needed in order to obtain information regarding the biological behavior of EBV-positive gastric carcinomas in Brazilian patients.

\section{References}

1. zur Hausen $H$, Schulte-Holthausen H, Klein G, Henle W, Henle G, Clifford P \& Santesson L (1970). EBV DNA in biopsies of Burkitt tumors and anaplastic carcinomas of the nasopharynx. Nature, 228: 1056-1058.

2. Shiramizu B, Barriga F, Neequaye J, Jafri A, Dalla-Favera R, Neri A, Guttierez M, Levine P \& Magrath I (1991). Patterns of chromosomal breakpoint locations in Burkitt's lymphoma: relevance to geography and Epstein-Barr virus association. Blood, 77: 1516-1526.

3. Weiss LM, Strickler JG, Warnke RA, Purtilo DT \& Sklar J (1987). Epstein-Barr viral DNA in tissues of Hodgkin's disease. American Journal of Pathology, 129: 86-91.

4. Weiss LM, Movahed LA, Warnke RA \& Sklar J (1989). Detection of Epstein-Barr viral genomes in Reed-Sternberg cells of Hodgkin's disease. New England Journal of Medicine, 320: 502-506. 
5. Jones JF, Shurin S, Abramowsky C, Tubbs RR, Sciotto CG, Wahl R, Sands J, Gottman D, Katz BZ \& Sklar J (1988). T-cell lymphomas containing Epstein-Barr viral DNA in patients with chronic EpsteinBarr virus infections. New England Journal of Medicine, 318: 733741.

6. Harabuchi Y, Yamanaka N, Kataura A, Imai S, Kinoshita T, Mizuno F \& Osato $T$ (1990). Epstein-Barr virus in nasal T-cell lymphomas in patients with lethal midline granuloma. Lancet, 335: 128-130.

7. Hamilton-Dutoit SJ, Pallesen G, Franzmann MB, Karkov J, Black F, Skinhoj P \& Pedersen C (1991). AIDS-related lymphoma: histopathology, immunophenotype, and association with Epstein-Barr virus as demonstrated by in situ nucleic acid hybridization. American Journal of Pathology, 138: 149-163.

8. MacMahon EM, Glass JD, Hayward SD, Mann RB, Becker PS, Charache P, McArthur JC \& Ambinder RF (1991). Epstein-Barr virus in AIDS-related primary central nervous system lymphoma. Lancet, 338: 969-973.

9. Wu TC, Mann RB, Epstein JI, MacMahon E, Lee WA, Charache P, Hayward SD, Kurman RJ, Hayward GS \& Ambinder RF (1991). Abundant expression of EBER1 small nuclear RNA in nasopharyngeal carcinoma: a morphologically distinctive target for detection of Epstein-Barr virus in formalin-fixed paraffin-embedded carcinoma specimens. American Journal of Pathology, 138: 1461-1469.

10. Niedobitek G, Young LS, Sam CK, Brooks L, Prasad U \& Rickinson $A B$ (1992). Expression of Epstein-Barr virus genes and lymphocyte activation molecules in undifferentiated nasopharyngeal carcinomas. American Journal of Pathology, 140: 879-887.

11. Krishnamurthy S, Lanier AP, Dohan P, Lanier JF \& Henle W (1987). Salivary gland cancer in Alaskan natives, 1966-1980. Human Pathology, 18: 986-996.

12. Leyvraz S, Henle W, Chahinian AP, Perlmann C, Klein G, Gordon RE, Rosenblum M \& Holland JF (1985). Association of Epstein-Barr virus with thymic carcinoma. New England Journal of Medicine, 312: 1296-1299.

13. Dimery IW, Lee JS, Blick M, Pearson G, Spitzer G \& Hong WK (1988). Association of Epstein-Barr virus with lymphoepithelioma of the thymus. Cancer, 61: 2475-2480.

14. Butler AE, Colby TV, Weiss L \& Lombard C (1989). Lymphoepithelioma-like carcinoma of the lung. American Journal of Surgical Pathology, 13: 632-639.

15. Burke AP, Yen TS, Shekitka KM \& Sobin LH (1990). Lymphoepithelial carcinoma of the stomach with Epstein-Barr virus demonstrated by polymerase chain reaction. Modern Pathology, 3: 377-380.

16. Min KW, Holmquist S, Peiper SC \& O'Leary TJ (1991). Poorly differentiated adenocarcinoma with lymphoid stroma (lymphoepithelioma-like carcinomas) of the stomach: report of three cases with Epstein-Barr virus genomes demonstrated by the polymerase chain reaction. American Journal of Clinical Pathology, 96: 219-227.

17. Shibata D, Tokunaga M, Uemura Y, Sato E, Tanaka S \& Weiss LM (1991). Association of Epstein-Barr virus with undifferentiated gastric carcinoma with intense lymphoid infiltration: lymphoepitheliomalike carcinoma. American Journal of Pathology, 139: 469-474.

18. Niedobitek G, Herbst H, Young LS, Rowe M, Dienemann D, Germer C \& Stein H (1992). Epstein-Barr virus and carcinomas: expression of the viral genome in an undifferentiated gastric carcinoma. Diagnostic Molecular Pathology, 1: 103-108.

19. Nakamura S, Ueki T, Yao T, Ueyama T \& Tsuneyoshi M (1994). Epstein-Barr virus in gastric carcinoma with lymphoid stroma. Cancer, 73: 2239-2249.

20. Oda K, Tamaru J, Takenouchi T, Mikata A, Nunomura M, Saitoh N, Sarashina H \& Nakajima N (1993). Association of Epstein-Barr virus with gastric carcinoma with lymphoid stroma. American Journal of Pathology, 143: 1063-1071.

21. Matsunou $H$, Konishi $F$, Hori $H$, Ikeda $T$, Sasaki $K$, Hirose $Y$ \& Yamamichi N (1996). Characteristics of Epstein-Barr virus-associated gastric carcinoma with lymphoid stroma in Japan. Cancer, 77: 1998-2004

22. Watanabe H, Enjoji M \& Imai T (1976). Gastric carcinoma with lymphoid stroma: its morphologic characteristics and prognostic correlations. Cancer, 38: 232-243.

23. Koriyama C, Akiba S, Iriya K et al. (2001). Epstein-Barr virus-associated gastric carcinoma in Japanese Brazilians and non-Japanese Brazilians in São Paulo. Japanese Journal of Cancer Research, 92: 911-917.

24. Brasil. Ministério da Saúde. Instituto Nacional de Câncer - INCA (2003). Estimativas da Incidência e Mortalidade por Câncer. INCA, Rio de Janeiro, RJ, Brazil.

25. Shibata D \& Weiss LM (1992). Epstein-Barr virus-associated gastric adenocarcinoma. American Journal of Pathology, 140: 769-774.

26. Shibata D, Hawes D, Stemmermann GN \& Weiss LM (1993). Epstein-Barr virus-associated gastric adenocarcinoma among Japanese Americans in Hawaii. Cancer Epidemiology Biomarkers and Prevention, 2: 213-217.

27. Gulley ML, Pulitzer DR, Eagan PA \& Schneider BG (1996). EpsteinBarr virus infection is an early event in gastric carcinogenesis and is independent of bcl-2 expression and p53 accumulation. Human Pathology, 27: 20-27.

28. Herrera-Goepfert R, Reyes E, Hernandez-Avila M, Mohar A, Shinkura R, Fujiyama C, Akiba S, Eizuru Y, Harada Y \& Tokunaga M (1999). Epstein-Barr virus-associated gastric carcinoma in Mexico: analysis of 135 consecutive gastrectomies in two hospitals. Modern Pathology, 12: 873-878.

29. Tokunaga $M$, Land CE, Uemura $Y$, Tokudome $T$, Tanaka S \& Sato E (1993). Epstein-Barr virus in gastric carcinoma. American Journal of Pathology, 143: 1250-1254.

30. Fukayama M, Hayashi Y, Iwasaki Y, Chong J, Ooba T, Takizawa T, Koike M, Mizutani S, Miyaki M \& Hirai K (1994). Epstein-Barr virusassociated gastric carcinoma and Epstein-Barr virus infection of the stomach. Laboratory Investigation, 71: 73-81.

31. Takano Y, Kato Y, Saegusa M, Mori S, Shiota M, Masuda M, Mikami T \& Okayasu I (1999). The role of the Epstein-Barr virus in the oncogenesis of EBV(+) gastric carcinomas. Virchows Archives, 434: 17-22.

32. Qiu K, Tomita $Y$, Hashimoto $M$, Ohsawa $M$, Kawano $K$, Wu DM \& Aozasa K (1997). Epstein-Barr virus in gastric carcinoma in Suzhou, China and Osaka, Japan: association with clinico-pathologic factors and HLA-subtype. International Journal of Cancer, 71: 155-158.

33. Yuen ST, Chung LP, Leung SY, Luk IS, Chan SY \& Ho J (1994). In situ detection of Epstein-Barr virus in gastric and colorectal adenocarcinomas. American Journal of Surgical Pathology, 18: 1158-1163.

34. Harn HJ, Chang JY, Wang MW, Ho LI, Lee HS, Chiang JH \& Lee WH (1995). Epstein-Barr virus-associated gastric carcinoma in Taiwan. Human Pathology, 26: 267-271.

35. Shin WS, Kang MW, Kang JH, Choi MK, Ahn BM, Kim JK, Sun HS \& Min KW (1996). Epstein-Barr virus-associated gastric adenocarcinomas among Koreans. American Journal of Clinical Pathology, 105: 174-181.

36. Chang MS, Lee HS, Kim CW, Kim YI \& Kim WH (2001). Clinicopathologic characteristics of Epstein-Barr virus-incorporated gastric cancers in Korea. Pathology, Research and Practice, 197: 395-400.

37. Galetsky SA, Tsvetnov VV, Land CE, Afanasieva TA, Petrovichev NN, Gurtsevitch VE \& Tokunaga M (1997). Epstein-Barr-virus-asso- 
ciated gastric cancer in Russia. International Journal of Cancer, 73: 786-789.

38. Selves J, Bibeau F, Brousset P, Meggetto F, Mazerolles C, Voigt JJ, Pradere B, Chiotasso P \& Delsol G (1996). Epstein-Barr virus latent and replicative gene expression in gastric carcinoma. Histopathology, 28: 121-127.

39. Ott G, Kirchner T \& Müller-Hermelink HK (1994). Monoclonal
Epstein-Barr virus genome but lack of EBV-related protein expression in different types of gastric carcinoma. Histopathology, 25: 323-329.

40. Hayashi K, Chen WG, Chen YY et al. (1998). Deletion of Epstein-Barr virus latent membrane protein 1 gene in Japanese and Brazilian gastric carcinomas, metastatic lesions, and reactive lymphocytes. American Journal of Pathology, 152: 191-198. 